\title{
ethic \\ PROTEÇÃO DA DIGNIDADE HUMANA DE MIGRANTES E REFUGIADOS: UMA PROPOSTA DE INTERVENÇÃO
}

\author{
PROTECTION OF THE HUMAN DIGNITY OF MIGRANTS AND \\ REFUGEES: A PROPOSED INTERVENTION
}

GABRIELE CORNELLI ${ }^{1}$

(UNB/Brasil)

INAYÁ POTYRA ${ }^{2}$

(UNB/Brasil)

SAVIO GONÇALVES DOS SANTOS ${ }^{3}$

(UNB/Brasil)

\begin{abstract}
RESUMO
Nos últimos anos o mundo tem visto se acentuar uma situação complexa: o aumento das migrações e de refugiados. Essa condição vem obrigando aos países diretamente afetados, sejam emissores ou receptores, a tomarem posições e definirem políticas específicas para o caso em questão. Além de impactos diretos nas relações diplomáticas, a condição dessas pessoas em situação de deslocamento, bem como o modo como elas têm sido tratadas, levantam preocupações de especialistas e autoridades. O desrespeito para com a dignidade, os casos de uso de violência como forma de resolução, bem como a condição vulnerável em que se encontram os transeuntes, são aspectos que motivam a abertura do diálogo e a proposição de saídas para a resolução do impasse. Urge resgatar as disposições normativas internacionais, que orientam as nações para a observância dos direitos individuais e da dignidade da pessoa humana. Especificamente, faz-se necessário que haja, por parte da Bioética, o desenvolvimento de uma proposta de ação para as sociedades, os migrantes e refugiados. Nesse sentido, a epistemologia latino-americana, através da Bioética de Intervenção (BI), apresenta um caminho socialmente comprometido, crítico, ativo e coletivista, mediante uma prática instrumentalista, que possibilita a transformação da realidade. Para tanto, estabelece-se a observância de três condições fundamentais: o desenvolvimento de ações coletivas que promovam a justiça/equidade e a autonomia; a consideração da cidadania expandida; e o estabelecimento de uma solidariedade crítica. Assim, pode-se contribuir com o estabelecimento de critérios político-sociais em busca do reconhecimento e garantia da dignidade da pessoa humana, especificamente dos refugiados e migrantes.
\end{abstract}

Palavras-chave: Migração; Dignidade Humana; Bioética; Intervenção

\begin{abstract}
In recent years the world has seen an arising of a complex situation: an increasing of migration and refugees. This situation obliges directly affected countries, whether emitters or receivers, to take positions and define specific policies to the case in question. In addition to direct impacts on diplomatic relations, the condition of those people in displacement, as well as the way they have been treated, raise concerns in experts and authorities. Disrespect for dignity, cases of use of violence as a form of resolution, as well as the vulnerable condition of the passers-by are aspects that motivate the opening for dialogue and the propose for solving such impasse. It is urgent to redeem international normative provisions, which guide nations towards observing individual rights and the dignity of the person. Specifically, it is necessary that Bioethics develop an action proposal for societies, migrants and refugees. In this sense, Latin American epistemology, through Bioethics of Intervention (BI), presents a socially committed, critical, active and collectivist path through an instrumentalist practice that enables a reality transformation. For
\end{abstract}


this, it is established the observance of three fundamental conditions: the development of collective actions that promote justice/equity and autonomy; the consideration of expanded citizenship; and the establishment of a critical solidarity. Thus, it is possible can contribute with the establishment of socio-political criteria searching for recognition and dignity guarantee of the human person, specifically of refugees and migrants.

Keywords: Migration; Human Dignity; Bioethics; Intervention

Introdução

Nos últimos anos o mundo tem assistido a inúmeras situações que levantam questionamentos sobre a condição do humano, especialmente no que tange à garantia de sua dignidade e direitos. Não que tais condições sejam novas no contexto global. Em seu "Origens do Totalitarismo", de 1951, Hannah Arendt já preconizava:

[...] Já não ansiamos por uma eventual restauração da antiga ordem do mundo com todas as suas tradições, nem pela reintegração das massas, arremessadas ao caos produzido pela violência das guerras e revoluções e pela progressiva decadência do que sobrou [...] (ARENDT, 2012, p. 25).

Especificamente, há um fator quer tem levado inúmeros países e instituições a debates e ações das mais variadas formas; trata-se da migração e dos refugiados. Essa realidade tem ganhado expressividade no contexto global, principalmente por conta do grande número de pessoas que se encontram nessas situações " [...] pelo desrespeito à dignidade humana e pela crescente violência na sua contenção, apesar da sua condição de extrema vulnerabilidade" (SILVA, 2017, p. 164). Dessa forma, o movimento migratório acaba por promover um paradoxo, ao se pautar a necessidade de garantias mínimas àqueles que chegam, independentemente da condição legal de sua entrada - migrantes ou refugiados -, em detrimento dos direitos e garantias dos países receptores e suas respectivas populações.

Se por um lado a resposta dada a tais situações, e condições, perpassa pela disposição normativa de que os Estados são detentores da mobilidade legitima (REIS, 2004, p. 150), numa espécie de expropriação da individualidade pessoal; que a autonomia dos Estados é algo intocável, sob o ponto de vista do direito internacional, que coloca em evidência a condição plena de soberania; por outro, há dispositivos internacionais que evocam a necessidade de se repensar a condição humana no contexto global, principalmente quando evidenciadas as agressões aos direitos universalmente aceitos, previstos nos documentos internacionais, como o Estatuto dos Refugiados (1970) e a Declaração Universal dos Direitos Humanos (DUDH). Fomentado por essa divergência 
[...] toma conta de diversos países um discurso político que condena qualquer forma de migração, e que, inclusive, deseja revisar alguns pontos do Estatuto dos Refugiados, como ficou claro no discurso de posse, proferido em 1998, da presidência rotativa da União Europeia, cujo representante pertencia a Áustria, que afirmou de forma contundente, a necessidade de se alterarem as normas que concedem o refúgio, alegando que ele vem sendo utilizado por pessoas que não se encaixam na sua descrição legal (BRAGA, 2011, p. 15).

Ao se aprofundar nas análises dos fatores migratórios e suas principais consequências, principalmente as evidentes transformações mundiais provocadas pelos fatores bélicos, não é difícil elencar quais justificativas se sobressaem como diretas responsáveis pelo permanente fenômeno da transumância, precursores de inúmeros debates, teorias, soluções e pseudosoluções ${ }^{4}$.

Entre tais fatores, ressalta-se a complexa relação econômica internacional (COSTA JÚNIOR, 2016, p. 19), que em muito converge para a comercialização de práticas da sociedade (SANDEL, 2012), transformando-as em práticas mercadológicas; as categorias de valor, ou mesmo a hierarquia de valores, que são estabelecidas pelos efeitos da globalização, e dispõe critérios, modelos, parâmetros do que deve ser tomado como mais importante e o que deve ser desconsiderado, ou atribuído uma relevância menor, criando assim, padrões que passam a ser globalmente impostos - evidencie-se aqui a disposição latente da mercantilização do humano, uma vez que "na segunda metade do século XX apareceu, todavia, uma concepção absolutamente nova com relação ao passado. Essa deriva dos progressos científicos que permitem a remoção, a modificação, a transferência e o uso, em benefício de outras pessoas [...] do corpo humano" (BERLINGUER, GARRAFA, 2001, p. 55).

Segundo dados do Alto Comissariado das Nações Unidas para Refugiados (ACNUR), disponíveis no relatório anual de "Tendências Globais" (Global Trends), que registra o deslocamento forçado no mundo, cerca de 65,3 milhões de pessoas foram deslocadas por guerras e conflitos até o final de 2015, um aumento de 10\% em relação ao ano de 2014. Desse total, 12,4 milhões são novos deslocados. Desse último conjunto, 8,6 milhões de pessoas foram obrigadas a mudar de local dentro do próprio país, deixando seus lares e 1,8 milhão cruzaram fronteiras em busca de melhores condições de vida, ou fugindo de situações-conflito. $\mathrm{O}$ universo total dessas pessoas inclui, ainda, 21,3 milhões de refugiados ao redor do mundo; 3,2 milhões de solicitantes de refúgio; e 40,8 milhões de deslocados. Ainda segundo a ACNUR, estima-se que exista cerca de 10 milhões de apátridas (ACNUR, 2015).

O mesmo relatório ainda apresenta uma análise acerca dos países de origem dos imigrantes e migrantes, a saber: a Síria aparece em primeiro lugar (4,9 milhões de pessoas), seguida pelo Afeganistão (2,7 milhões) e Somália (1,1 milhão). Por sua vez, os países com 
maior número de deslocados internos são: Colômbia (6,9 milhões), Síria (6,6 milhões) e o Iraque (4,4 milhões). Em relação a novos deslocamentos internos, o Iêmen foi o que apresentou o maior número de pessoas (2,5 milhões), representando cerca de $9 \%$ de sua população (ACNUR, 2015).

Todas essas disposições levantam questionamentos acerca da condição humana, de sua dignidade como um todo e da necessária criação de formas e meios para preservar o direito humano universal diante da migração e seus efeitos. Assim, o objetivo do presente texto se constroi sobre uma dinâmica de intervenção, fundada num modelo bioético latino-americano conhecido como Bioética de Intervenção, que busca ser a voz dos migrantes e refugiados, bem como atuar na garantia de que todas as pessoas em deslocamento possuem direitos que devem ser respeitados, protegidos e satisfeitos; e que refugiados e solicitantes de refúgio sejam protegidos por uma estrutura legal específica.

Os tratados internacionais e a personalidade internacional

A integração global, acelerada pelos modernos meios de comunicação com divulgação de fatos e imagens em tempo real e com grande capilaridade, provoca reflexos também no Direito Internacional. Antes, sujeitos clássicos de Direito Internacional Público (DIP) eram os Estados Soberanos, dotados de autoridade estatal sobre seu povo e território que podiam, coercitiva e indistintamente, controlar o fluxo humano além-fronteiras, entre outras atividades monopolistas. Na atualidade, esse poder dos estados internacionais sofre revisão para admitir limitações, influenciado pelo olhar crítico dos Direitos Humanos, onde aquela soberania tradicional dos estados foi substituída por uma "soberania da humanidade" (RAMOS, 2005). Assim, um Estado que viole regras internacionais não "pode" invocar seu direito doméstico para evitar críticas ou represálias internacionais e a soberania não "pode" acobertar violações de Direitos Humanos (SHELTON, 2015).

Passou-se de um sujeito único de direito internacional para a inclusão das Organizações Internacionais, finalizando a descentralização com o reconhecimento da pessoa humana também como sujeito de direitos e de deveres na esfera externa, onde essa pode agora figurar ativamente em peticionamentos aos Tribunais Internacionais, ou pode ser passivamente responsabilizada por eles, ou seja, indivíduos passam a ter personalidade e capacidade jurídica internacional.

O surgimento do Tribunal Penal Internacional (TPI) também colaborou na nova conformação do DIP e na percepção da personalidade jurídica internacional da pessoa humana, 
quando estabeleceu (art. $1^{\circ}$.), que as pessoas responsáveis por crimes de maior gravidade com alcance internacional estarão sob sua jurisdição. O Direito Internacional dos Direitos Humanos (DIDH) surgiu como um conjunto de normas para proteger os direitos que os seres humanos possuem; esses direitos humanos ${ }^{5}$ são universais, ancorados não na racionalidade, mas em sentimentos humanos comuns a todos os membros da espécie (RORTY, 2015, p. 26). Firmados pela Revolução Francesa, os princípios da liberdade, igualdade e fraternidade consubstanciaram, dentre outros documentos, a Declaração Universal de Direitos Humanos (DUDH, 1948).

Em que pese a dificuldade de se impor limites à atuação estatal internacional persistir (GOODWIN-GILL, 2016), os direitos humanos 'são clamores morais que os estados são obrigados a respeitar no seu sistema-legal' (CARENS, 2013). Para consubstanciar essa nova visão do indivíduo como pessoa, ressalte-se a importância das normas internacionais costumeiras (customery law), de cunho cogente para toda a comunidade internacional pelo uso reiterado de práticas com fins humanitários que se perpetuam na História. São 'leis-morais', tais como as normas costumeiras do Direito Internacional Humanitário (DIH), "como a proibição do recurso da força e as normas que tutelam o patrimônio comum da humanidade" (MELLO, 1997, p. 2). O costume tem uma força moral influenciadora e a DUDH hoje é entendida como norma costumeira (SCHUTTER, 2014) e erga omnes.

Importante se faz ressaltar que, como um ramo do DIP o DIDH tem certas peculiaridades, como a sua não sujeição ao princípio da reciprocidade, onde qualquer desrespeito aos direitos humanos por um Estado não enseja uma ação recíproca de outrem; nem mesmo uma violação da paz, por um Estado, faculta que outros estados violem os direitos humanos em retaliação. A título de exemplificação, tem-se a impossibilidade de embargo de material médico e alimentício a um Estado ainda que violador dos direitos humanos.

Uma outra característica é a sua progressividade, isto é, o sistema de proteção de DH vem sendo construído lentamente com a História e ao lado de normas jurídicas costumeiras, acordos jurídicos expressos de são firmados, contendo inerentemente a capacidade/especificidade de poder diminuir a atuação da soberania do Estado, se necessário, diferentemente de outros ramos do DIP, cujos acordos jurídicos tem capacidades vinculativas opcionais ou até denunciáveis pelos Estados.

Apesar das leis nacionais evidenciarem a necessidade da garantia dos direitos humanos, como o caso das constituições nacionais, é comum a recepção e aplicação de leis internacionais. Tais leis são originadas em Declarações, Tratados, Direito Costumeiro ${ }^{6}$, princípios gerais e outras fontes de DIP. Os direitos humanos consolidam-se também pelas decisões das Cortes 
Internacionais as quais progressivamente ampliam a proteção da personalidade internacional atribuída ao indivíduo, para defendê-lo até mesmo das atrocidades lançadas por seu Estado natal.

A proteção internacional da pessoa humana, assim, se dá por três vertentes: dos Direitos Humanos, do Direito Internacional Humanitário e do Direito dos Refugiados. Esse entendimento se aprimorou para entrelaçar as três vertentes num único veio de proteção, cada qual complementando e ou suprindo lacunas porventura existentes, eis que as três objetivam a proteção da pessoa humana (TRINDADE, 1996, p. 30). Tendo já delineado os contornos do primeiro, passar-se-á aos dois seguintes, corroborando o entendimento do reconhecimento formal da pessoa humana como sujeito de direito internacional.

Eis então que ao se tratar de DIH, está-se a tratar do conjunto de normas destinadas a dosimetrar os meios e métodos de combate armado, a proteger os feridos, doentes e náufragos, a população civil (evitando que seja atacada e que seja deslocada forçadamente) e o patrimônio material e imaterial, indispensáveis à sobrevivência da população local/global (bens culturais, meio ambiente) dentro de uma zona de conflito armado. As fontes do DIH são de origem consuetudinária, mas foram amplamente codificadas durante o século XX e, na maior parte dos casos, continuam a ter um valor consuetudinário para os Estados que não ratificaram nem aderiram aos textos convencionais (DEYRA, 2001, p. 19).

A terceira vertente de proteção internacional da pessoa humana refere-se ao Direito Internacional dos Refugiados. Importante relembrar a diferença terminológica entre migrante e refugiado, para caracterização da responsabilidade de proteção dessas pessoas. Enquanto o migrante pressupõe o voluntariado nos deslocamentos, em busca de melhores condições socioeconômicas ou fugindo de catástrofes ambientais ${ }^{5}$, o refugiado tem caracterizado sua condição pela Convenção de Genebra (1951) e seu Protocolo de 1967, além de outros documentos internacionais. $\mathrm{O}$ 'refugiado' carrega consigo o fundado temor de/ou a perseguição por motivo de raça, opinião pessoal, grupo social e não quer/não pode permanecer no Estado que lhe ameaça, enquanto o migrante carrega o estigma da pobreza, o fato de ser indocumentado, a falta de permissão do país receptor para adentrar e lá permanecer, movido grande e fortemente pela aporofobia. Essa diferenciação, reconhecida como 'nexo causal' da migração, não poderia ser motivo para imputação de tratamentos discriminatórios a esses indivíduos e deveria ambos usufruírem da proteção internacional, independentemente de seu rótulo 'legal'.

Dentre os princípios consagrados para a proteção dos refugiados, constantes da Convenção de 1951, estão o princípio da não-discriminação; o estatuto pessoal do refugiado; a 
proibição da punição por entrada ou permanência irregular no país onde se solicita refúgio; as normas sobre trabalho e documentos de identificação e o princípio do non-refoulement ${ }^{7}$, que determina que os indivíduos não possam ser impedidos de adentrar um território de refúgio no país receptor nem serem enviados contra a sua vontade para seu estado de origem, ou outro local onde possam ser expostos a perseguição/morte, torturas ou tenham sua dignidade e integridade física ameaçadas. Além do Princípio do non-refoulement, o Princípio da Repatriação (em terceiro país) exsurge como norma jus cogen e ambos se complementam, pois significam a garantia de liberdade, emprego, saúde, dignidade da pessoa humana e autodeterminação.

Também devem ser envidados esforços no sentido de o refugiado poder retornar ao seu país com dignidade, com políticas de restabelecimento social e econômico do país emissor visando reintegrá-lo na comunidade internacional e dar-lhe condições de receber seus nacionais.

A convergência entre as vertentes de proteção fica visível também quando se observa o dever jurídico de proteger esses indivíduos, constante da DUDH, que estabelece o direito de asilo em qualquer país em caso de perseguição; no Pacto dos Direitos Civis e Políticos, Pacto dos Direitos Econômicos, Sociais e Culturais, todos garantindo o direito à vida, à solidariedade entre os povos e à saúde.

O Sistema de Direitos Humanos da ONU, constituído por órgãos instituídos pela Carta (órgãos da Carta) ou por tratados (órgãos baseados em tratados), verificam o cumprimento das normas de direitos humanos. O entendimento internacional, até mesmo consagrado em julgamentos das Cortes Internacionais, revela que as Convenções/Declarações de Direitos Humanos da ONU, tais como sobre Direitos Civis e Políticos, a Convenção contra a Tortura e outros Tratamentos ou Penas Cruéis, Desumanos ou Degradantes, são consideradas normas jus cogen, portanto de seguimento imperativo. Integrando ainda o sistema de proteção dos DH da ONU (embora não pertencendo estritamente a ela, constam ainda o Tribunal Penal Internacional, outros Tribunais internacionais, Agências especializadas e Conferências internacionais.

No sistema de proteção regional, tem-se o Tribunal Europeu de Direitos Humanos a Corte Interamericana de Direitos Humanos e o Sistema Africano de Direitos Humanos, que permitem seu acionamento por indivíduos (ainda que representados por uma Comissão, no caso da Corte Americana e Africana), reconhecendo deste modo a sua capacidade jurídica.

Demonstrado assim parte do arcabouço internacional de proteção da pessoa humana resta comentar sobre o Tribunal Penal Internacional (TPI), que define e julga infrações perpetradas por indivíduos (não julga Estados) agora com reconhecida capacidade jurídica de 
direito internacional, eis que as violações ali julgadas são as responsáveis por grande parte dos deslocamentos forçados no mundo: o TPI, formalizado pelo Estatuto de Roma (ER, 1998) consubstanciou a jurisdição sobre "pessoas", agora responsáveis pelos crimes de genocídio, crimes contra a humanidade, crimes de guerra e crimes de agressão ${ }^{8}$. O TPI, em que pese o teor dos crimes sob sua competência, genuinamente crimes contra a pessoa humana, somente tem alcance de punibilidade para os membros dos países que lhe são signatários. Isso significa que ainda há países que não ratificaram o ER alegando defesa de sua soberania e, portanto, podem impedir a punição por crimes atrozes de seus nacionais. Apesar dessa ‘insubmissão’ de Estados, dependendo do crime cometido há possibilidade de ações serem coibida/punida complementarmente pelo DIDH, por suas normas consideradas de jus cogen com alcance erga omnes. Nas experiências anteriores de Tribunais penais especialmente constituídos (ad hoc) para apuração dos crimes perpetrados na Iugoslávia e em Ruanda, sua constituição sempre demandou maior articulação política e esses tiveram sua força coercitiva de certo modo 'restringida' por serem tribunais precários, cuja constituição era especifica e por prazo certo, diferentemente do TPI que é permanente.

Defensores da teoria da internacionalização dos direitos do homem, atribuem grande peso a essa transição de responsabilidade objetiva do Estado para responsabilidade subjetiva do autor, conseguida formalmente com o TPI. De forma geral o que se nota é que o DIP se orienta no sentido do reconhecimento da pessoa humana como personalidade jurídica internacional. Porém, quando a teoria jurídica é posta à prova, como recentemente na chamada "crise de refugiados" (que já foi intitulada 'crise de migrantes', no passado, mas as conveniências políticas alteraram a denominação), a proteção dos deslocados não é efetivamente cumprida.

A Bioética de Intervenção e a dignidade da pessoa humana

Pautar o surgimento da Bioética enquanto uma disciplina independente, supõe considerar dois aspectos complementares. A princípio, tal propositura advém dos trabalhos e ideias, no início dos anos 70, de Van Rensselaer Potter, médico norte-americano, que trouxe consigo uma possível resposta às inúmeras inquietações e conflitos que encerravam a marcante década de 60.

A retomada da preocupação mundial com as questões morais nos anos 60 movimentou três setores essenciais: a) a ética dos negócios, através da qual diversos países passaram a atacar de forma mais dura a corrupção e outros abusos verificados no setor econômico-financeiro; b) a ética ambiental, que se estabeleceu principalmente através 
de avanços com relação aos movimentos de defesa da preservação e às leis de proteção ao meio ambiente; c) a bioética (GARRAFA, 1997, p. 1).

A preocupação de Potter estava centrada em desenvolver uma proposta de ação crítica, que direcionasse esforços em apontar formas e meios para se garantir a sobrevivência humana. Dessa forma, ele pautou as bases dessa ciência numa concepção epistemológica capaz de lidar com o contexto global, que envolveria cientistas e humanistas num só movimento.

[...] Esta nova ciência, bioethics, combina o trabalho dos humanistas e cientistas, cujos objetivos são sabedoria e conhecimento. A sabedoria é definida como o conhecimento de como usar o conhecimento para o bem social. A busca de sabedoria tem uma nova orientação porque a sobrevivência do homem está em jogo. Os valores éticos devem ser testados em termos de futuro e não podem ser divorciados dos fatos biológicos. Ações que diminuem as chances de sobrevivência humana são imorais e devem ser julgadas em termos do conhecimento disponível e no monitoramento de "parâmetros de sobrevivência" que são escolhidos pelos cientistas e humanistas (POTTER, 1971, p. 6-7).

O segundo aspecto, também relevante, acerca do surgimento, ou desenvolvimento, da Bioética, tem suas referências num texto escrito por Fritz Jahr, um teólogo alemão, onde ele fez questão de ligar a Bioética às obrigações éticas com relação a todos os seres vivos. Esse relato foi confirmado, em 2012, num evento promovido pelo Círculo de Estudos Interdisciplinares de Ética Médica - Polônia/Alemanha, cujo o tema era "1927 - O nascimento da Bioética, em Halle pelo Teólogo Protestante Fritz Jahr". Nele, o professor Florian Steger apresentou o surgimento da Bioética fundado num contexto do Imperativo Bioético, em 1926, no periódico "Die Mittelschule", onde Jahr apresenta o termo "Bio-Ethik" (HOSS, 2013, p. 84). Mesmo se considerando tal contexto, o meio acadêmico admite que a paternidade da Bioética é realmente de Potter, principalmente por todos os desenvolvimentos teóricos que ele veio a realizar enquanto presidente do National Cancer Institute, nos Estados Unidos (GARRAFA, 2012, p. 741).

A projeção alcançada pelas teorias de Potter levou a Bioética, já no seu auge teórico, a passar por comportamentos reducionistas, que acabaram por minimizar o potencial de análise ampliada que o autor queria (DURAND, 2003). Curiosamente, foi exatamente dessa forma, reduzida, que a Bioética acabou difundida no contexto mundial. Entre os referenciais adotados, ela preconizava a prática individualista e a autonomia dos sujeitos (GARRAFA, 2012, p. 742). Entretanto, o que se assistiu alguns anos depois, motivado em grande parte pela publicação do Relatório de Belmont (1978), foi uma virada da ideia original para uma Bioética voltada às questões biomédicas. Cerca de um ano após a publicação do relatório, o livro Principles of 
Biomedical Ethics, de Tom Beauchamp e James Childress, arrastou a Bioética para uma proposta de apologia aos quatro princípios fundamentais norteadores, já previstos no Relatório de Belmont (Autonomia, Beneficência, Não-maleficência e Justiça), modelo esse que se convencionou chamar de Principialista.

Por mais que o principialismo desponte, na maioria das instituições que pesquisam e trabalham com a Bioética, como única referência a ser seguida, essa leitura acabou sendo alvo de inúmeras críticas; entre as quais pode-se citar: o posicionamento moralista, que acabava por impor os princípios como obrigação; a inexistência de um modelo de ação defensável que se justifique; o apontamento dos princípios como ideais morais, o que, por vezes pode demonstrar incoerência textual; a superlativação da autonomia em detrimento dos demais princípios; o discurso de poder, que acabava emergindo das fundamentações principialistas; e a impossibilidade de se analisar os princípios de maneira crítica (MARTORELL, 2015). O que se percebe é que o posicionamento epistemológico apresentado pela Bioética Principialista acaba mantendo e legitimando estruturas de poder e, de maneira direta, converte-se numa Bioética ineficaz para diversas realidades plurais, especialmente a enfrentada por este trabalho.

A partir das transformações globais, especialmente nos campos econômico e tecnológico, com a evidenciação da globalização como parâmetro regulador das ações, acentuou-se a divisão já existente entre países ricos e pobres, centrais e periféricos, gerando uma hierarquia nas relações entre esses e, consequentemente, entre os cidadãos (PORTO; GARRAFA, 2005, p. 115). A exclusão e discriminação dos cidadãos residentes nos países pobres e periféricos; a inacessibilidade tecnológica que apregoa segregação; a ameaça constante à dignidade; a relativização do direito à vida; a sobreposição do mercado em detrimento do humano; as guerras constantes; o sonho de uma vida digna e com qualidade, forçam as pessoas a abandonarem seus lares, suas terras, provocando esse, não novo, mas intenso, fenômeno da migração e consequente crescimento de solicitações de refúgio - numa constante que se origina nos países periféricos em direção aos centrais. Todas essas condições, e seus respectivos e variados resultados, evocam respostas urgentes e ações imediatas, no intuito de salvaguardar a pessoa humana em sua personalidade internacional - como visto.

[...] as condições em que a passagem é realizada, normalmente em pequenas embarcações ou mesmo em simples botes, os quais não são suficientes para garantir segurança perante as ondas do mar mediterrâneo, produzindo desoladoras imagens de corpos pairando nas praias, aguardando a fria identificação e o holofote da mídia internacional, como foi o caso do garoto Aylan Kurdi, de 3 anos encontrado em praia (WITHNALL, 2015). 
Contudo, por interesses diversos, essas pessoas acabam condenadas, em muitos dos casos, à própria sorte, uma vez que a maioria dos países receptores não discute a situação humanitária, mas tão somente a salvaguarda de si e dos seus, vulnerabilizando os demais.

\begin{abstract}
Em virtude de crescente e rápido afluxo de migrantes na Europa, a EU definiu, em junho de 2014, as "orientações estratégicas da programação legislativa e operacional no espaço de liberdade, segurança e justiça" para o período 2014-2020, tratando-se apenas de orientações gerais para aplicação e consolidação dos instrumentos jurídicos e das medidas políticas já em vigor em matéria de migração (COSTA JÚNIOR, 2015, p. 27).
\end{abstract}

Toda essa realidade fragiliza a ação em busca dos direitos humanos e, ao mesmo tempo, conclama uma epistemologia bioética - crítica - que consiga, se não resolver, propor soluções de enfrentamento para tais condições. Esse comportamento vai ao encontro das propostas assumidas pela Bioética a partir dos anos 90, até a contemporaneidade. De maneira geral, isso significou lidar com

\begin{abstract}
A necessidade de se enfrentar de modo ético e concreto as questões sociais e sanitárias mais básicas, como a exclusão social ou a equidade no atendimento sanitário, conjuntamente à universalidade do acesso das pessoas aos benefícios do desenvolvimento científico e tecnológico. Este último aspecto, extremamente atual, diz respeito à ética da responsabilidade pública do Estado diante dos cidadãos, no que se refere à priorização, à decisão, à alocação, à distribuição e ao controle de recursos financeiros direcionados às ações de saúde (GARRAFA, 2012, p.744, grifo nosso).
\end{abstract}

Para além dessas concepções abrangentes da Bioética, ainda é possível argumentar, de maneira direta, acerca do seu papel multi-intertransdisciplinar. Isso significa assumir a fusão dos caráteres de multidisciplinaridade, interdisciplinaridade e transdisciplinaridade, definidos pela DUBDH. É preciso assim, admitir às práticas bioéticas, novos parâmetros de ação, voltados para além das questões biomédicas. É exatamente em vistas ao cumprimento desse comportamento que nasce a Bioética de Intervenção (BI), foco do presente texto.

Nascida no ocaso da etapa de revisão crítica (anos 90) e no alvorecer da etapa de ampliação conceitual (anos 2000 até o presente) da Bioética, a BI parte da propositura de um modelo bioético afirmativo, ativo, dialogal, inclusivo, político e, principalmente, coletivista. Tal modelo tem como base de ação a construção de respostas e meios para o enfrentamento de conflitos que exigem flexibilização, adequação de culturas, macroproblemas cotidianos e complexidades específicas. Trata-se de uma proposta oriunda dos países periféricos diretamente afetados pelo processo de globalização econômica mundial, que aprofundou as desigualdades 
entre as nações ricas e pobres, onde o principialismo não é suficiente (GARRAFA, 2012, p. 743-744).

\begin{abstract}
A teoria dos quatro princípios - de certo modo já revisada em seu "núcleo duro" e pretensamente universalista pelos seus próprios proponentes na $5^{\mathrm{a}}$ edição do livro "Principles of biomedical ethics" - apesar de sua reconhecida praticidade e utilidade para análise de situações clínicas e em pesquisa - é sabidamente insuficiente para: a) análise contextualizada de conflitos que exijam flexibilidade para uma determinada adequação cultural; b) enfrentamento de macroproblemas bioéticos persistentes ou cotidianos enfrentados por grande parte da população de países com significativos índices de exclusão social como o Brasil e seus vizinhos da América Latina e Caribe (GARRAFA, 2005, p. 131-132).
\end{abstract}

$\mathrm{O}$ aporte necessário para a sustentação da propositura da BI, advém da ascensão das bases epistemológicas dos países periféricos, evidentes na construção e na essência da DUBDH. Isso significou admitir a possibilidade existencial de aspectos morais diferenciados, vindos de culturas e comportamentos múltiplos. Essa condição reconhece ainda, a dificuldade de admitir princípios éticos universais desconexos com a realidade local. Isso não significa eliminar os fundamentos da Bioética, bem como recusar sua construção epistemológica, pelo contrário. Admite-se a abertura de espaço gerador de reflexões específicas dos países periféricos, direcionadas também para uma contribuição global. Como prova dessa mudança, e da não compreensão abrangente das demais bioéticas, é possível elencar os seis referenciais conceituais da Bioética aliada à realidade latino-americana (GARRAFA; KATTOW; SAADA, 2006):

1. A não universalidade das diferentes situações, com necessidade de contextualização dos problemas específicos em exame, dos respectivos referenciais culturais, religiosos, políticos, de preferência sexual etc.

2. O respeito ao pluralismo moral, a partir das visões morais diferenciadas sobre os mesmos assuntos e constatadas nas sociedades plurais e democráticas do século XXI.

3. A inequívoca aptidão da bioética para constituir um novo núcleo de conhecimento necessariamente multi-intertransdisciplinar.

4. A característica de ser uma ética aplicada, ou seja, originária da filosofia e comprometida em proporcionar respostas concretas aos conflitos que se apresentam.

5. A análise dos fatos a partir dos referenciais do pensamento complexo ou da totalidade concreta. Isso, contudo, não significa o simples somatório das partes de uma determinada situação, mas sua interpretação estruturada em rede, em que todos os conceitos e elementos se iluminam mutuamente, proporcionando uma noção mais harmônica e palpável de realidade a partir da religação de diferentes saberes.

6. A necessidade de estruturação do discurso bioético, que deve ter como base a comunicação e a linguagem (para se manifestar), a argumentação (que deve primar pela homogeneidade e lógica), a coerência (na exposição das ideias) e a tolerância (relativa ao convívio pacífico diante de visões morais diferenciadas). 
Relevando a importância de cada um dos seis referenciais, a BI se coloca como uma ética aplicada, com vistas a contribuir, com respostas e ações diretas, em contextos sociais primordialmente conflitantes, como o caso da migração e dos refugiados, em busca de dar voz àqueles que não possuem; justifica-se, dessa forma, a intervenção nesses mesmos contextos. Cabe ressalvar que essa proposta intervencionista não pode ser confundida com intromissão. Ela se perfaz pela busca e manutenção da autonomia, da consciência e da liberdade dos que, de alguma forma, foram impedidos de exercê-las. A escolha da BI como meio para a ação em relação aos migrantes e refugiados, dá-se por sua característica instrumentalista e não meramente epistemológica; pois,

[...] essa nova proposta teórica busca uma aliança concreta com o lado historicamente mais frágil da sociedade, incluindo a reanálise de diferentes dilemas, entre os quais: autonomia versus justiça/equidade; benefícios individuais versus benefícios coletivos; individualismo versus solidariedade; omissão versus participação; mudanças superficiais e temporárias versus transformações concretas e permanentes (GARRAFA; PORTO, 2003, p. 401).

Uma segunda razão para suster a opção pela BI está centrada no marco teórico por ela estabelecido, que determina a necessidade de intervenção. Trata-se da corporeidade: o prazer, a dor, a personalidade, a dignidade, não utilitarista, onde o humano não seja colocado e tratado como mero objeto. É esse corpo que mantém a totalidade humana em suas dimensões bio-psicosocial. Exatamente por isso é que o movimento inicial da BI se dá através da análise desse corpo e as interpretações que dele derivam. Essa condição envolve, inclusive e fundamentalmente, a disposição crítica acerca do meio em que esse humano se encontra, bem como a influência de um sobre o outro. Projeta-se, dessa forma, ações que visem à garantia da inviolabilidade das condições para que as pessoas consigam suster suas vidas (GARRAFA; PORTO, 2005, p.117118). Vale ressaltar que apesar de ser de origem brasileira, voltada para a realidade latinoamericana, a BI tem caráter global. "Es una propuesta conceptual y práctica que pretende avanzar en el contexto internacional, a partir de América Latina" (GARRAFA; PORTO, 2008, p. 190, grifo nosso)

Ao se considerar a situação dos migrantes e refugiados, bem como a permanente agressão às suas dignidades, aos seus corpos, a supressão do reconhecimento e garantia da personalidade internacional da pessoa humana, a BI se insurge como uma necessária intervenção em favor daqueles e daquelas que estão nessas condições. Apoiada em documentos internacionais da ONU, especialmente a Declaração Universal sobre Bioética e Direitos Humanos (DUBDH), de 2005, e sempre em que houver ameaças à sobrevivência, supressão de 
direitos, desvalorização de culturas, hierarquização de pessoas, a BI age em busca da evidenciação de responsabilidades irrevogáveis, seja no campo público e coletivo, ou no privado e individual, independentemente do país e sua legislação.

A primeira constatação feita através da BI é o desrespeito de muitos dos países receptores aos documentos internacionais. Por mais que as cartas internacionais evidenciem a necessidade de se respeitar a cidadania dos que se encontram em situação de migrantes ou refugiados, a lógica da subjetividade e da soberania estatal acabam por se sobreporem. Assim, a primeira proposta de ação, efetiva, para a situação da migração e de refúgio, é que os países busquem decisões que "privilegiem o maior número de pessoas durante o maior espaço de tempo possível e que resulte nas melhores consequências" e ainda "[...] soluções viáveis e práticas para os conflitos localmente identificados, levando em consideração o contexto em que ocorrem e as contradições que os fomentam" (PORTO; GARRAFA, 2005, p. 115).

De maneira objetiva, a BI propõe que se busque tomar como critério de análise o paradoxo existente entre a autonomia e a justiça/equidade. Isso supõe considerar que garantir a autonomia das pessoas em situação de vulnerabilidade é fundamental, e que essa mesma autonomia se encontra limitada, seja pela falta da liberdade ou capacidade de plena decisão e escolha sobre sua própria vida. Junte-se a isso a promoção da justiça - aqui entendida como equidade - que caminha de encontro à própria DUBDH e seus artigos. Não significa dizer, em contrapartida, que os países receptores terão sua autonomia tolhida, por conta da heteronomia; mas é preciso frisar a necessidade do respeito às diferenças como promoção da justiça. $\mathrm{O}$ primeiro passo para compreender de que maneira o respeito tem ligação com a justiça é considerá-lo como um valor fundamental para que uma sociedade seja tomada como justa. Esse entendimento se associa ao que John Rawls chamou de "sociedade bem ordenada" (well ordered Society); teoria na qual haveria a necessidade da escolha de dois princípios de justiça por indivíduos que desconheçam as condições, tanto pessoais, quanto sociais.

Especificamente no primeiro princípio, Rawls faz menção aos bens sociais primários que devem ser assegurados por um critério de justiça. Vale ressaltar que a concepção de Rawls acerca da justiça está diretamente ligada à ideia de equidade, como o próprio afirma:

Todos os valores sociais - liberdade e oportunidade, renda e riqueza, e as bases sociais do autorrespeito - devem ser distribuídos igualmente, a menos que uma distribuição desigual de um, ou de todos, esses valores sejam para a vantagem de todos (RAWLS, 1999, p. 54). 
O que Rawls defende, portanto, é a garantia de que os bens sociais precisam ser divididos igualmente; é uma proposta de reconhecimento da cidadania ${ }^{9}$, que ratifica a segunda proposta de ação da BI. A inexistência de tal reconhecimento provoca consequências graves, como a perda da garantia dos direitos fundamentais e políticos, o que solapa as disposições presentes na DUBDH, assinadas por inúmeros países membros da ONU. Para a resolução dessa questão, e garantia efetiva dos direitos universais, ratificados pelos códigos internacionais, temse a proposta do reconhecimento e garantia da cidadania expandida, que se traduz na concretização do direito coletivo à igualdade e a equidade, dispostos a indivíduos, grupos e segmentos (PORTO; GARRAFA, 2005, p. 115). A cidadania expandida supõe, em primeiro plano, o reconhecimento efetivo, e inalienável, da pessoa em sua integralidade, para além das garantias e parâmetros normativos específicos de cada Estado. Em segundo, a extensão de todos os direitos dessa mesma pessoa, independentemente de sua origem. Tais direitos incluem: sobrevivência física e social; condições de manutenção e qualidade de vida; e a preservação dos recursos naturais e a vida em um ambiente saudável. Essa garantia possibilita o empoderamento das pessoas, garantindo, assim, a complementação da dignidade.

A terceira proposta de ação da BI se dá na efetivação da Solidariedade Crítica. Pois a BI

[...] prevê o uso da reflexão baseada também na solidariedade crítica. O prazer das pessoas deve ser desejável, mas, quando há uma única possibilidade de intervenção, deve-se levar em consideração a realidade social vivida pelas pessoas envolvidas, não com um olhar compadecente de piedade, mas com a noção de que alguns prazeres devem ser elencados acima de outros (SILVA; DRUMMOND; GARRAFA, 2011, p. 111).

Essa que não se faz de uma solidariedade hipócrita, para mera satisfação pessoal de quem a realiza. A Solidariedade Crítica propõe esse reconhecimento do outro, numa prática permanente de alteridade e organicidade. É a disposição perene do reconhecimento e da garantia da diversidade, em busca da plenitude da vida. Essa realidade supõe valorizar a autonomia das pessoas, refutando meras práticas assistencialistas, promovendo a prática da libertação e do engajamento para a resolução de problemas coletivos, garantindo a integralidade. Integralidade que pressupõe a possibilidade de uma vida digna e com qualidade, independente de condições específicas, e requer o compromisso com categorias necessárias, tais como: "responsabilidade", "cuidado", "solidariedade", "comprometimento", "alteridade" e "tolerância" por parte de todos e, especialmente, dos países receptores (GONÇALVES, 2005, p. 112).

A garantia da integridade vai de encontro a quarta proposta da BI: os quatro "P's". Em toda ação humana, há a necessária consideração de quatro aspectos, que se convertem em ações 
preventivas. Assim, tem-se: Prudência, frente aos avanços; Prevenção, de possíveis danos; Precaução, frente ao desconhecido; e Proteção, dos mais frágeis e desassistidos (GARRAFA; PORTO, 2008, p. 191-192). Em se tratando dos migrantes e refugiados, a BI propõe Prudência nas ações e propostas com relação a essas pessoas, uma vez que todas devem ser reconhecidas como únicas e exclusivas. Não pode haver, nas práticas assumidas, comportamento que mingue os direitos humanos e os individuais, mesmo que não sejam, num primeiro momento, reconhecidos como cidadãos. Quanto à Prevenção, refere-se à adoção de comportamentos específicos e necessários para os casos de migração e refúgio, que visem a minimizar os danos que possam ser causados aos indivíduos e suas famílias. Superar práticas desnecessárias, como as vistas em alguns países, de separação das crianças de suas famílias, e disposições discriminatórias e desumanas de segregação e exclusão por mera diferença cultural e étnica; ou mesmo por considerações e ideologias políticas. Nesse aspecto, o ser humano não pode ser minimizado em seus reconhecimento, direitos e garantias, em detrimento de acordos e posicionamentos político-eleitoreiros.

O terceiro ponto de atenção e disposição em busca da promoção da justiça, é a Precaução. Ela deve ser adotada mediante realidades e situações desconhecidas - que não significa não existentes, mas novos problemas para determinados países - para lidar com essa realidade desconhecida e emergente. Esse aspecto teórico faz jus ao que a BI considera como "situações emergentes" ${ }^{10}$. Dentro dessa compreensão, a ação está diretamente voltada para a atenção com as populações que sofreram algum tipo de agressão direta, por conta de políticas e comportamentos de outras nações e povos. $\mathrm{O}$ assumir dessa postura ratifica a urgência em se atentar para a situação vivida pelas pessoas em situação de migração e refúgio. Por fim, o último “P”, aponta para a obrigatória Proteção aos frágeis e desassistidos. Trata-se de uma disposição para enfrentar os modelos hegemônicos que afrontam a dignidade humana, colocando-se ao lado dos mais vulneráveis. É fundamental abrir o diálogo com as autoridades em prol dessas pessoas que se encontram desprotegidas. Evocar a supremacia da condição humana, do debate em prol de consenso, evita que determinadas decisões sejam tomadas de maneira monocrática e autoritária. Dar voz aos migrantes e refugiados não significa tapar os ouvidos aos clamores locais, é antes não incorrer no erro de suprir direitos humanos em prol de vontades subjetivas. Somente assim é possível pensar em uma humanidade em continuo movimento e, principalmente, na resolução dos conflitos causados por este encontro de populações e culturas.

A intervenção necessária apoiada na BI leva, inevitavelmente, à conquista e à manutenção dos direitos universais que sustentam a dignidade da pessoa humana, transpondo as barreiras que impedem seu reconhecimento e efetividade. Mais do que simples prática 
garantista, abrir-se ao diálogo e propor ações diretas significam a existência humana, aprofundando a lógica do eu-outro-nós, alçando a promoção da justiça.

Tratar das questões dos migrantes e refugiados pode evocar a discussão sobre o papel da Bioética no contexto social, ou mesmo político. Para muitos bioeticistas, ela não pode se propor, de maneira direta, à solução de situações e problemas específicos, pois se trata de uma disciplina fundada na discussão e no desenvolvimento de conceitos e fundamentos. Entretanto, o que não se pode deixar de observar, é que a Bioética não se compõe de uma mera disciplina abstrata e distante do real. Ao contrário, ela precisa ser comprometida socialmente, localmente e globalmente. Urge atentar-se para o fato de que

bioeticistas ainda não tenham se dado conta de que há situações aéticas nas sociedades contemporâneas, que têm uma profunda ressonância no pensar e fazer da bioética [...]. Refiro-me ao fenômeno pancultural da opressão de gênero, ao recrudescimento do racismo e a xenofobia no mundo e aos prejuízos e discriminações baseados na classe social, orientação sexual e idades (OLIVEIRA, 2006, p. 65).

A BI surge nesse contexto de resposta às situações elencadas pela bioeticista Fátima Oliveira. Não se admite um comportamento bioético acrítico, distante do contexto real e descompromissado com a sociedade. É uma ação permanente no sentido de atingir e minimizar, de maneira efetiva, esses fomentos de vulnerabilidade. Assim, obrigatoriamente, a Bioética precisa admitir uma prática correlacionada com questões políticas e jurídicas, como o caso em questão, em busca da promoção da dignidade humana. Essa leitura comprometida assumida pela BI, faz com que a compreensão e o entendimento das questões sejam acentuados, pois possibilitam uma interpretação da interseccionalidade ${ }^{11}$ dessas mesmas vulnerabilidades, numa disposição prática multi-intertransdisciplinar; o que as demais formas de Bioética, Biopolítica e Biodireito não alcançam.

Conclusão

Os refugiados têm percorrido a cada dia mais as estradas do mundo. $\mathrm{O}$ destino de milhões de homens, mulheres, crianças já não pode ser ignorado. Fato é que o mundo vem passando pelo maior movimento forçado de pessoas da história, conforme aponta o Relatório Anual de Tendências Globais da ONU (ACNUR, 2015). Tal realidade tem movimentado o cenário geopolítico internacional e feito surgir inúmeras propostas de ação. Com muita frequência a reação dos países que são procurados para asilo é de fechamento das fronteiras e a aglomeração dos refugiados em campos de contenção. Em muitas dessas ações promovidas 
pelos países receptores, evidencia-se a agressão permanente à dignidade das pessoas em situação de migração e refúgio. É, de fato, a concretização do apregoado por Arendt.

Inegável, faz-se ressaltar, a autonomia dos Estados receptores, inclusive por conta da organização local e a possibilidade da manutenção dessa mesma dignidade para os nativos. Entretanto, referenciais não faltam para demonstrar que, em muito dos casos, não há a preocupação com os migrantes e refugiados, abandonados à própria sorte. $\mathrm{O}$ que se quis evidenciar, além da condição humana - ponto fulcral - é o modo como o humano é fruto do seu meio e o meio pode ser manipulado. Acostumada a essa realidade, a bioética latinoamericana não pode se furtar a contribuir com a reflexão global e com a estruturação de ações que busquem apontar caminhos e formas de ação. O primeiro passo dado nessa proposta é o reconhecimento, fundamental, da personalidade internacional. Essa condição se apoia em documentos internacionais, conforme o demonstrado, na busca permanente da manutenção da vida e sua dignidade. Tal reconhecimento e, em verdade, o necessário assumir da responsabilidade para com o outro e com o coletivo que, inevitavelmente, impacta no nós.

Paradoxal se faz propor uma prática que valorize ações localmente construídas, abertas ao diálogo e fundadas na participação de todos, inclusive dos migrantes e refugiados e, ao mesmo tempo, sustentar uma proposta global. Entretanto, é preciso evidenciar o fato de que o presente trabalho quer apontar uma saída para o enfrentamento global, uma vez que, em grande parte, as ações não são orientadas para todos os envolvidos (COLLIER, 2013). É o movimento subjetivista e discriminatório, evidenciado por Costa Júnior (2016, p. 19) que se quer combater, e evitar a não garantia dos direitos humanos. É reconhecer as diferenças e as igualdades na construção da equidade em busca da justiça. É a prática da cidadania expandida, baseada no direito coletivo e internacional. É a alteridade que deve se apresentar à autonomia para a construção da heteronomia.

A BI, apresentada como meio para o enfrentamento da situação dos migrantes e refugiados, não propõe uma intervenção direta, como num processo de supressão dos direitos, liberdade e autonomia. Ao contrário, essa intervenção de justifica quando não há, de alguma forma, na realidade humana, prudência nas propostas e considerações de ação; prevenção dos danos a todos os envolvidos; precaução nas ações antes de serem realizadas; e proteção para os que não podem se proteger, ou têm, de alguma forma, seus direitos minimizados ou agredidos. Com isso, a BI propõe a universalização e a garantia da dignidade humana como caminho para o enfrentamento das situações de migração e refúgio na realidade global contemporânea. 


\section{Notas}

${ }^{1}$ Professor Associado da Universidade de Brasília. Coordenador do Programa de Pós-Graduação em Metafísica e docente permanente do Programa de Pós-Graduação em Bioética. Brasília, DF, Brasil. E-mail: cornelli@unb.br

${ }^{2}$ Mestranda no Programa de Pós-graduação em Bioética da Cátedra Unesco de Bioética da Universidade de Brasília (UnB). Brasília, DF, Brasil. E-mail: inayapotyra@gmail.com

${ }^{3}$ Doutorando no Programa de Pós-graduação em Bioética da Cátedra Unesco de Bioética da Universidade de Brasília (UnB). Brasília, DF, Brasil. E-mail: oivasavio@gmail.com

${ }^{4}$ Justifica-se aqui a utilização do termo pseudosolução, pois uma das propostas do presente artigo é demarcar que, em verdade, o que muito se propõe como caminho para solucionar, ou mesmo amenizar, a situação dos migrantes somente favorece, em sua maioria, os países receptores, não dispensando à devida atenção aos direitos das pessoas.

5“[...] soma dos direitos civis, políticos, econômicos, sociais, culturais e coletivos estipulados pelos instrumentos internacionais e regionais e pelo costume internacional" (NOWAK, 2003, p. 1).

${ }^{6} \mathrm{O}$ Direito Costumeiro, por se traduzir em normas oriundas do convívio humano em sociedade, quase sempre se reveste de valores universais e aplicáveis contra todos e a todos os sujeitos de DIP, ou seja, norma jus cogen. Há a doutrina que entende que o jus cogen é formado apenas por normas costumeiras, assim como outras entendem haver normas convencionais com essa característica e outros ainda que somente a admitem para normas costumeiras de Direitos Humanos. Na hierarquia das normas, tratados e costumes estão no mesmo grau hierárquico.

${ }^{7}$ A natureza jus cogens do princípio do non-refoulement garante a proteção internacional da pessoa e dos seus direitos humanos, incluindo a possibilidade de se responsabilizar internacionalmente os Estados ou organizações internacionais que violem essa norma. Ainda segundo a Resolução 52/132 de 12 de dezembro de 1997, acerca desse princípio, a Assembleia Geral das Nações Unidas afirma "that the principle of non-refoulement is not subject to derogation".

${ }^{8}$ Esse último ainda não foi capitulado pelo Estatuto de Roma, apesar da insistência de muitos países signatários que tentaram fazê-lo durante a 1 ${ }^{\mathrm{a}}$. Conferência de Revisão do E.R, em Uganda-2010.

${ }^{9}$ Ressalte-se que, a princípio, os migrantes e refugiados não possuem jus sanguinis (vínculo sanguíneo) com algum nato e nem jus solis (vínculo territorial) com algum desses Estados - aspectos fundamentais para o reconhecimento da cidadania.

${ }^{10}$ Um duplo embasamento prático-teórico da BI está direcionado à compreensão, análise e ação direta em situações conhecidas como emergentes e persistentes. As situações emergentes, primam pelo trabalho direto com problemas, situações e conflitos, oriundos dos avanços técnico-científicos dos últimos anos, tais como: novas tecnologias reprodutivas, transplantes de órgãos e tecidos humanos, engenharia genética e todos seus desdobramentos, terapia celular, respeito à biodiversidade etc. Já as situações persistentes em bioética, a BI centra esforços em debelar problemas, situações e conflitos oriundos de contradições sociais, bem como a realidade de populações marginalizadas, e as consequências daí derivadas: exclusão social, pobreza, analfabetismo, discriminação e estigmatização, equidade, alocação de recursos escassos, aborto, entre outros (GARRAFA, 2012, p. 756).

11 A interseccionalidade é o entendimento de que determinada vulnerabilidade não se forma somente de um aspecto; mas sim, advém de um entrecruzamento de fatores que acaba por aguçar a problemática de todas elas (CRENSHAW, 1994). 
Referências

ACNUR. Relatório Anual de Tendências Globais. 2015. Disponível em http://www.acnur.org/portugues/recursos/estatisticas/. Acesso em 9 maio 2017.

ARENDT, Hannah. Origens do Totalitarismo. Tradução de Roberto Raposo. São Paulo: Companhia das Letras, 2012. 827 p.

BERLINGUER, Giovanni; GARRAFA, Volnei. O mercado humano. 2. ed. Tradução de Isabel Regina Augusto. Brasília: Editora Universidade de Brasília, 2001. 252 p.

BRAGA, Jorge Luiz Raposo. Os campos de refugiados: um exemplo de "espaços de exceção" na política contemporânea. In: $3^{\circ}$ ENCONTRO NACIONAL ABRI 2011. Proceedings online... São Paulo: Associação Brasileira de Relações Internacionais, Instituto de Relações Internacionais - USP, 2011. Disponível em:

http://www.proceedings.scielo.br/scielo.php?pid=MSC0000000122011000200036\&script=sci arttext. Acesso em: 27 nov. 2018.

CARENS, Joseph H. The Ethics of Immigration. Oxford: Oxford University Press, 2013. 386 p.

COLLIER, Paul. Exodus: How Migration is Changing Our World. New York: Oxford University Press, 2013. p. 11-26.

COSTA JÚNIOR, Carlos Nogueira da. Crise Migratória na Europa em 2015 e os Limites da Integração Europeia: uma abordagem multicausal. Rev. Conjuntura Global, 2016; 5(1): 1933.

CRENSHAW, Kimberlé Williams. Mapping the margins: intersectionality, identity politics, and violence against women of color. In: FINEMAN, Martha Albertson; MYKITIUK, Roxanne. The public nature of private violence. New York: Routledge, 1994. p. 93-118.

DEYRA, Michel. Direito Internacional Humanitário. Brasília: Gab. Doc. Direito Comaparado (GDDC), 2001. p. 19.

DURAND, Guy. Introdução Geral à Bioética. São Paulo: Loyola, 2003.

GARRAFA, Volnei. Bioética. IN: GIOVANELlA, Ligia et al. Políticas e Sistemas de Saúde no Brasil. 2. ed. Rio de Janeiro: Editora Fiocruz/Centro Brasileiro de Estudos de Saúde, 2012. $1100 \mathrm{p}$.

$1-5$.

. Da bioética de princípios a uma bioética interventiva. Rev. Bioética, 1999; 7(1):

. Reflexões bioéticas sobre ciência, saúde e cidadania. Rev. Bioética

GARRAFA, Volnei; PORTO, Dora. Intervention bioethics: a proposal for peripheral countries in a context of power and injustice. Rev. Bioethics, 2003; 17: 399-416. 
Bioética de intervenção: considerações sobre a economia de mercado. Rev.

Bioética, 2005; 13(1): 115.

Bioética de intervención. In: Tealdi JC, director. Diccionario latinoamericano de bioética. Bogotá: Unesco, 2008: 191-192.

GARRAFA, Volnei; KOTTOW, Miguel; SAADA, Alya. (Orgs.) Bases Conceituais da Bioética: enfoque latino-americano. São Paulo: Gaia, Unesco, 2006.

GONÇALVES, Erli Helena. Desconstruindo o preconceito em torno do HIV/Aids na perspectiva da bioética de intervenção. Brasília. Tese Doutorado em Bioética - Universidade de Brasília, 2005. 112 p.

GOODWIN-GILL, Guy S. The International Law of Refugee Protection. In: FIDDIANQASMIYEH, Elena; LOESCHER, Gil; LONG, Katy; SIGONA, Nando. The Oxford Handbook of Refugee and Forced Migration Studies. Oxford University Press: 2016. 784 p.

HOSS, Geni Maria. Fritz Jahr e o Imperativo Bioético: debate sobre o início da Bioética na Alemanha e sua importância em nível internacional. Rev. Bioethikos, 2013; 7(1): 84-86.

MARTORELL, Leandro Brambilla. Análise crítica da Bioética de Intervenção: um exercício de fundamentação epistemológica. Brasília. Tese Doutorado em Bioética - Universidade de Brasília, 2015. 113p.

MELLO, Celso Duvivier de Albuquerque Mello. Direitos Humanos e conflitos armados. São Paulo: Renovar, 1997. 496 p.

NOWAK, Manfred. Introduction to the international Human Rights Regime. Boston: Martinus Nijhoff, 2003. 382 p.

OLIVEIRA, Fátima. Condición socioeconómica, de género y raza/etnia en las investigaciones biomédicas. In: KEYEUX, Genoveva; PENSCHASZADEH, Victor; SAADA, Alya (Coord.) Ética de la investigación en seres humanos y politicas de salud pública. Bogotá:

UNESCO/Red Latinoamericana y del Caribe/Universidad Nacional de Colombia: 2006. p. 65.

PETERKE, Sven (Org.). Manual Prático de Direitos Humanos. Brasília: Escola Superior do Ministério Público da União, 2009. 374 p.

PORTO, Dora; GARRAFA, Volnei. Bioética de intervenção: considerações sobre a economia de mercado. Rev. Bioética, 2005; 13(1): 115.

POTTER, Van Rensselaer. Bioethics: bridge to the future. Englewood Cliffs: Prentice-Hall, 1971.

RAWLS, John. A theory of justice. Revised edition. Cambridge, Massachusetts: The Harvard University Press, 1999. 
REIS, Rossana Rocha. Soberania, Direitos Humanos e Migrações Internacionais. Rev. Brasileira de Ciências Sociais, 2004; 19(55): 149-164.

RORTY, Richard. Human Rights, Recionality and Sentimentaly. In: ALBUQUERQUE, Aline. Direitos Humanos dos Pacientes. Curitiba: Juruá, 2015. p. 26.

SANDEL, Michael. Justiça: o que é fazer a coisa certa. 6. ed. Rio de Janeiro: Civilização Brasileira, 2012. $350 \mathrm{p}$.

SHELTON, Dinah. Remedies in International Human Rights Law. 3. ed. Oxford: Oxford University Press, 2015. 512 p.

SHUTTER, Olivier de. International Human Rights Law. 2. ed. Cambridge: Cambridge University Press, 2014. 1121 p.

SILVA, Daniela Florêncio da. O fenômeno dos refugiados no mundo e o atual cenário complexo das migrações forçadas. Rev. Bras. Est. Pop., 2017; 34(1): 163-170.

SILVA, Leonardo Eustáquio Sant'Anna da; DRUMMOND, Adriano; GARRAFA, Volnei. Bioética de intervenção: uma prática politizada na responsabilidade social. Rev. Universitas, 2011; 9(2): 111-19.

TRINDADE, Antônio Augusto Cançado. As três vertentes da proteção internacional da pessoa humana - da compartimentalização à interação. In: PEYTRIGNET, Gérard; RUIZ DE SANTIAGO, Jaime. As três vertentes da proteção internacional dos direitos da pessoa humana: direitos humanos, direito humanitário, direito dos refugiados. San José da Costa Rica/ Brasília: Instituto Interamericano de Direitos Humanos, Comitê Internacional da Cruz Vermelha, Alto Comissariado das Nações Unidas para os Refugiados, 1996, p. 30

WITHNALL, Adam. Aylan Kurdi's story: How a small Syrian child came to be washed up on a beach in Turkey. The Independent. Londres. 3 set. 2015. Disponível em:

http://www.independent.co.uk/news/world/europe/aylan-kurdis-story-how-a-smallsyrianchild-came-to-be-washed-up-on-a-beach-in-turkey-10484588.html. Acesso em: 9 maio 2017. 